Article

\title{
The Phytochemical, Antifungal, and First Report of the Antiviral Properties of Egyptian Haplophyllum tuberculatum Extract
}

\author{
Ahmed Abdelkhalek ${ }^{1, *(\mathbb{C}}$, Mohamed Z. M. Salem ${ }^{2, *}{ }^{\mathbb{D}}$, Elsayed Hafez ${ }^{1}$, Said I. Behiry ${ }^{3}$ \\ and Sameer H. Qari ${ }^{4}$ (D) \\ 1 Plant Protection and Biomolecular Diagnosis Department, ALCRI, City of Scientific Research and \\ Technological Applications, New Borg El Arab, Alexandria 21934, Egypt; elsayed_hafez@yahoo.com \\ 2 Forestry and Wood Technology Department, Faculty of Agriculture (El-Shatby), Alexandria University, \\ Alexandria 21545, Egypt \\ 3 Agricultural Botany Department, Faculty of Agriculture (Saba Basha), Alexandria University, \\ Alexandria 21531, Egypt; said.behiry@alexu.edu.eg \\ 4 Biology Department, Al-Jumum University College, Umm Al-Qura University, Mecca 25376, Saudi Arabia; \\ shqari@uqu.edu.sa \\ * Correspondence: abdelkhalek2@yahoo.com (A.A.); mohamed-salem@alexu.edu.eg (M.Z.M.S.)
}

Received: 14 July 2020; Accepted: 22 August 2020; Published: 25 August 2020

\begin{abstract}
In this study, ethanol whole plant extract (WPE) of Haplophyllum tuberculatum was characterized and tested for its antifungal and antiviral activities against Fusarium culmorum, Rhizoctonia solani and tobacco mosaic virus (TMV). High Performance Liquid Chromatography (HPLC) analysis showed that the main phytochemical constituents of H. tuberculatum WPE were resveratrol $(5178.58 \mathrm{mg} / \mathrm{kg})$, kaempferol $(1735.23 \mathrm{mg} / \mathrm{kg})$, myricetin $(561.18 \mathrm{mg} / \mathrm{kg})$, rutin $(487.04 \mathrm{mg} / \mathrm{kg})$, quercetin $(401.04 \mathrm{mg} / \mathrm{kg})$, and rosmarinic acid $(387.33 \mathrm{mg} / \mathrm{kg})$. By increasing $H$. tuberculatum WPE at concentrations of $1 \%, 2 \%$, and $3 \%$, all of the fungal isolates were suppressed compared to the two positive and negative controls. Under greenhouse conditions, WPE-treated Chenopodium amaranticolor plants strongly inhibited TMV infection and significantly reduced TMV accumulation levels when compared to non-treated plants. Moreover, the induction of systemic resistance with significant increases in the transcriptional levels of the pathogenesis-related protein-1 (PR-1), chalcone synthase $(\mathrm{CHS})$, and hydroxycinnamoyl-CoA quinate transferase $(H Q T)$ genes for treated plants were noticed at 3 and 5 days post-inoculation (dpi) for both assays. To the best of our knowledge, this is the first reported observation of the antiviral activity of $H$. tuberculatum extract against plant viral infections. Finally, the results obtained suggest that $H$. tuberculatum WPE can be considered a promising source of both antifungal and antiviral substances for practical use and for developing plant-derived compounds for the effective management of plant diseases.
\end{abstract}

Keywords: Haplophyllum tuberculatum; phytochemical analysis; HPLC analysis; antifungal property; tobacco mosaic virus; antiviral activity

\section{Introduction}

Haplophyllum is a genus belonging to the Rutaceae family. It is distributed in different floristic regions. The plant is rich in alkaloids, fixed oils, volatile oils, furanocoumarins, and several classes of compounds such as alkaloids, lignans, coumarins, and flavonoids have been isolated from the aerial parts of Haplophyllum tuberculatum [1]. Globally, plant viral diseases constitute severe threats to sustainable development and modern agriculture [2]. Among these viruses, the tobacco mosaic virus (TMV) is one of the most common viral diseases that causes economic losses of and severe damage to 
quality and crop production worldwide [3,4]. Besides ranking in the top 10 plant viruses in molecular plant pathology, TMV is used as a model virus, and Chenopodium amaranticolor as a TMV-local lesion host for different biological studies [5]. Insect-borne viruses such as TMV and cucumber mosaic virus (CMV) can be controlled well by applying induced resistance (IR), even by a biological or chemical inducer [6,7]. In addition, in Egypt, the production of tomato faces the problem of insect-borne viruses, which are very difficult to manage because of their wide host range [8]. Systemic acquired resistance (SAR) is an inducible defense mechanism that plays a central role in disease resistance [9]. Moreover, the chemical induction of SAR treatment induces both pathogenesis-related (PR) protein accumulation and resistance to viruses, bacteria, and the fungus in Arabidopsis plants [10].

Recently, it has been demonstrated that the chemical induction of SAR treatment of vegetable plants protects them against root rot diseases [11]. Several biotic stresses can affect tomato plants more so than other vegetables. Moreover, they are capable of remaining in soil and plant residues for an extended period of time [12]. The soil-borne pathogenic fungus "biotic stresses" can lead to a decrease in crop production of the Rhizoctonia solani plant, which causes several injures in the bean of tomato crops [13]. Fusarium spp. are an abundant saprophyte in soil and organic matter and are found worldwide. Some strains cause vascular wilt disease in plants, including vegetables, bananas, and date palms such as Fusarium culmorum.

Most fungal species, such as the Fusarium, Rhizoctonia, and Penicillium species, cause mold and discolor wood-based products $[14,15]$. However, chemical fungicides can induce further problems, harming other living organisms by reduction of useful soil microorganisms [16]. Therefore, alternative methods of pest control could be an approach to reduce the use of pesticides. For instance, biological control strategies are slowly replacing harmful pesticides due to the acceleration of developed biological control products and commercialized forms [17]. Recently, there has been a trend to develop an environmentally safe, long-lasting chemical fungicide based on plant metabolites as an alternative for the control of Fusarium diseases, benomyl, and captafol [18,19]. Many plants exhibit antifungal activities that could produce a variety of secondary metabolites against phytopathogenic fungi [20-22]. Plant-derived natural products and bioactive compounds include phenols, phenolic acids, quinones, flavones, flavonoids, flavonols, tannins, and coumarins, which are well-known examples for biofungicides [23-26].

The mycelial radial growth of Fusarium oxysporum is reduced by Azadirachta indica, Calotropis procera, Citrullus cololcynthis, Datura stramonium, and Nicotiana tabacum extracts [27]. Furthermore, Cinnamomum burmanni leaf aqueous extract efficiently suppresses the biomass and spore formation of F. oxysporum f. sp. lycopersici [28]. Meanwhile, the ethanol extracts from Lowsonia inermis and Psidium guajava are effective in inhibiting the Fusarium pathogen [29].

Most approaches applied to control TMV include treating plants with chemical pesticides or using breeding and transgenic plants. However, chemically synthetic pesticides harm the environment and human health; also, transgenic plants have not yet been universally accepted [30]. Therefore, there is still a high demand for discovering more alternative, environmentally friendly, and effective antiviral methods.

Plants are rich sources of bioactive constituents with an antiviral activity that can develop environmentally friendly methods of disease management [31]. Reports of the antiviral activities of plant crude extracts and their constituents against plant viral infection have increased during the last decade [32]. Many plant extracts of Boerhaavia diffusa, Clerodendrum aculeatum, Mirabilis jalapa, Potentilla arguta, Sambucus racemosa, and Thuja orientalis exhibit inhibitory effects against plant viruses [33-37]. Additionally, several virus-inhibiting compounds, including flavonoids, triterpenoids, alkaloids, and proteins, have been isolated from higher plants [31].

H. tuberculatum extracts have been noticed to exhibit insecticidal [38], nematicidal [39], antifungal, and antibacterial properties $[40,41]$. The polyphenolic and alkaloid compounds in the ethyl acetate extract from the leaves of $H$. tuberculatum may be significant contributors to the antioxidant activity of these extracts [42]. Leaf oil extracted from $H$. tuberculatum shows strong anticandidal activity against 
Candida krusei at $30 \mu \mathrm{g} / \mathrm{mL}$ [43]. Also, essential oil has been found to inhibit the growth of Curvularia lunata and F. oxysporum [40].

The present study aimed to analyze the protective activity and inactivity of the ethanol extract of H. tuberculatum against the TMV for the first time. Additionally, the changes in the transcriptional levels of some defense-related genes and TMV accumulation levels at different time intervals were evaluated. Moreover, the antifungal properties of $H$. tuberculatum were assessed against two molecularly identified fungal isolates, namely, F. culmorum and R. solani.

\section{Materials and Methods}

\subsection{Preparation of the H. tuberculatum Extract and HPLC Analysis of Phenolic Compounds}

Whole plants (WP) of H. tuberculatum collected from the northwest of Egypt in April 2018 were air-dried at room temperature for one week. The dried WP was ground to a fine powder using a small laboratory mill. Approximately $100 \mathrm{~g}$ of the powdered WP of $H$. tuberculatum was extracted by the soaking method [44] with $200 \mathrm{~mL}$ of ethanol solvent for three days. After the extraction process was finished, the extract was filtered through a cotton plug and then with Whatman No. 1 filter paper. The filtered extract was concentrated by evaporating the ethanol solvent to obtain the H. tuberculatum whole plant extract (WPE). To prepare the concentration of the extract, the H. tuberculatum WPE was dissolved in dimethyl sulfoxide $(10 \% \mathrm{DMSO}=10 \mathrm{~mL}$ DMSO $(99.999 \%)+90 \mathrm{~mL}$ distilled water), and the concentrations levels of $1 \%, 2 \%$, and $3 \%$ were obtained. Then, 1,2 , and $3 \mathrm{~g}$ from the extract were dissolved in $100 \mathrm{~mL}$ of $10 \%$ DMSO to obtain the extract concentrations of $1 \%, 2 \%$, and $3 \%$, respectively. The extract was analyzed for its polyphenolic compounds using Agilent 1260 Infinity HPLC Series (Agilent, Santa Clara, CA, USA), equipped with a Quaternary pump and a Zorbax Eclipse Plus C18 column $(100 \times 4.6 \mathrm{~mm}$ i.d. $)$ in $H$. tuberculatum WPE [15,44-48]. The analysis was carried out based on the 23 standard phenolic compounds [47].

\subsection{Antifungal Property of Wood Treated with H. tuberculatum WPE}

F. culmorum and R. solani as common molds were used for the antifungal bioassay previously isolated from twigs, trunks, and roots were collected from sweet orange trees showing cankers, dry root rot, wilt and decline at Bader district, Egypt. The isolated fungal colonies were characterized morphologically and molecularly by the internal transcribed spacer region of the rDNA (ITS) gene and the amplified fragments were sequenced and the generated sequences were deposited in Genbank under accession numbers MH352452 and MH352450, respectively [49,50]. Briefly, Melia azedarach wood samples were air-dried and prepared with an approximate dimension of $0.5 \times 1 \times 1 \mathrm{~cm}$. The prepared wood samples were autoclaved for $20 \mathrm{~min}$ at $121^{\circ} \mathrm{C}$, and then left to cool. Three wood samples were used for each concentration for each fungus, as well as for the positive ( $25 \mu \mathrm{g}$ of fluconazole) and negative (10\% DMSO) controls. The antifungal activity of the wood-treated extract in terms of the inhibition percentage of fungal linear growth (IPFLG) was measured following our previous work [15,49-51], using the following formula; IPFLG $(\%)=\left[\left(G_{C}-G_{T}\right) / G_{C}\right] \times 100$, where $G_{C}$ and $G_{T}$ represent the average diameters of the fungal colony of control and treatment, respectively.

\subsection{Source of Virus, Inoculum Preparation and Antiviral Activity Assays}

Egyptian TMV strain KH1 (Acc\# MG264131) was propagated in N. tabacum and purified as previously described [52]. Then, $50 \mu \mathrm{L}$ of $20 \mu \mathrm{g} / \mathrm{mL}$ TMV, diluted with $0.1 \mathrm{M}$ phosphate buffer, $\mathrm{pH}$ 7.2, was used as the viral inoculum. The prepared concentration of the WPE of H. tuberculatum $(200 \mu \mathrm{g} / \mathrm{mL})$ diluted with sterile distilled $\mathrm{H}_{2} \mathrm{O}$ was prepared from a stock solution of $2 \%$ of $H$. tuberculatum WPE dissolved in DMSO. A mixture of equal volumes of DMSO and sterile distilled $\mathrm{H}_{2} \mathrm{O}$ was used as the negative control. By using the half-leaf method [47,53], with C. amaranticolor as a TMV-local lesion host, the assessment of the antiviral activity of WPE was evaluated according to the inhibition percentage toward number of local lesions. The inhibitory effects were calculated according to the following 
formula: $[\mathrm{I}=(1-\mathrm{T} / \mathrm{C}) \times 100]$, where $\mathrm{I}$ is the inhibition effect, $\mathrm{T}$ is the number of local lesions on the treated halves of the leaves, and $C$ is the number of local lesions on the non-treated halves of the leaves.

\subsection{Protective and Inactivity of WPE Assays}

Under greenhouse-controlled conditions, $C$. amaranticolor seeds were surface sterilized and sown in plastic pots $(20 \mathrm{~cm}$ in diameter) filled with sterilized soil. At the 5-6th leaf stage, plants were subjected to two assays, and each assay had three treatments replicated three times.

In the protective assay, the upper-right halves of the leaves were treated with $H$. tuberculatum WPE $24 \mathrm{~h}$ before mechanical viral inoculation. In contrast, the upper-left halves of the leaves were inoculated with TMV only without any treatment $[54,55]$. Mock leaves treated with a mixture of equal volumes of DMSO, sterile distilled $\mathrm{H}_{2} \mathrm{O}$, and phosphate buffer with carborundum were used as the controls. The local lesion development numbers were recorded at $3-5$ days post-inoculation (dpi).

In the inactivity assay, the upper-right halves of the leaves were mechanically inoculated with an $H$. tuberculatum WPE-TMV mixture, in which an equal volume of $H$. tuberculatum WPE was mixed with the same amount of purified TMV and incubated for $1 \mathrm{~h}$. In contrast, the upper-left halves of the leaves were mechanically inoculated with TMV only without any treatment. The observed number of local lesions was recorded $4-5$ dpi.

\subsection{Plant Total RNA Extraction and cDNA Synthesis}

Total RNA was extracted from the C. amaranticolor halve of the leaves ( $0.1 \mathrm{~g}$ fresh weight), which were collected at 3 and 5 dpi using the RNeasy plant mini kit according to the manufacturer's instructions (QIAGEN, Hilden, Germany). After treatment with RNase-free DNase to eliminate genomic DNA, the concentration and quality of the extracted RNA were determined at A260/A280 and A260/A230 using SPECTROstar Nano (BMG Labtech, Ortenberg, Germany). In contrast, the integrity of the RNA was assessed by the agarose gel electrophoresis technique [56]. First-strand cDNA was synthesized using $1 \mu \mathrm{g}$ of total RNA with random oligohexamers and oligo (dT) primers, as described previously [57]. Then, RT-PCR was performed in two steps: $42^{\circ} \mathrm{C}$ for $1 \mathrm{~h}$ and then $72{ }^{\circ} \mathrm{C}$ for $10 \mathrm{~min}$. The reaction mixture was stored at $-20{ }^{\circ} \mathrm{C}$ until used.

\subsection{Quantitative Real-Time PCR ( $q P C R)$ Assay and Data Analysis}

The effects of $H$. tuberculatum WPE on the expression of the accumulation levels of the TMV and C. amaranticolor defense system were studied using the qPCR technique. Different primer sets (Table 1) specific to pathogenesis-related protein-1 (PR-1), chalcone synthase (CHS), hydroxycinnamoyl-CoA quinate transferase (HQT), and TMV coat protein (CP) genes were used in this study. The housekeeping gene $\beta$-actin (Table 1 ) was used as a reference gene for the normalization of the transcript expression levels. The qPCR efficiency was determined for each gene and was between $93 \%$ and $100 \%$ for all genes. Each sample in all reactions was run in triplicate on a Rotor-Gene 6000 (QIAGEN, ABI System, Hilden, Germany) using the SYBR Green PCR Master Mix (Fermentas, Waltham, MA, USA) [58]. The single and discrete peak of the melting curve analysis at $55-95^{\circ} \mathrm{C}$ confirmed the single amplified product for all genes. The amplification programs and the relative expression ratios were accurately quantified and calculated, as described previously [59,60]. Relative expression levels of more than 1 demonstrate an increase in accumulation (i.e., up-regulation), while values lower than 1 show a decrease in expression (i.e., down-regulation). 
Table 1. Nucleotide sequences of the qRT-PCR primers used in this study.

\begin{tabular}{|c|c|c|c|c|}
\hline Primer Name & Abbreviation & Direction & Sequence $\left(5^{\prime}-3^{\prime}\right)$ & References \\
\hline Pathogenesis-related protein-1 & $P R-1$ & $\begin{array}{l}\text { Forward } \\
\text { Reverse }\end{array}$ & $\begin{array}{l}\text { CCAAGACTATCTTGCGGTTC } \\
\text { GAACCTAAGCCACGATACCA }\end{array}$ & [61] \\
\hline Chalcone synthase & CHS & $\begin{array}{l}\text { Forward } \\
\text { Reverse }\end{array}$ & $\begin{array}{c}\text { CACCGTGGAGGAGTATCGTAAGGC } \\
\text { TGATCAACACAGTTGGAAGGCG }\end{array}$ & [62] \\
\hline $\begin{array}{l}\text { Hydroxycinnamoyl Co A quinate } \\
\text { hydroxycinnamoyl transferase }\end{array}$ & $H Q T$ & $\begin{array}{l}\text { Forward } \\
\text { Reverse }\end{array}$ & $\begin{array}{l}\text { CCCAATGGCTGGAAGATTAGCTA } \\
\text { CATGAATCACTTTCAGCCTCAACAA }\end{array}$ & [62] \\
\hline Beta-actin & $\beta$-actin & $\begin{array}{l}\text { Forward } \\
\text { Reverse }\end{array}$ & $\begin{array}{l}\text { ATGCCATTCTCCGTCTTGACTTG } \\
\text { GAGTTGTATGTAGTCTCGTGGATT }\end{array}$ & [63] \\
\hline Tobacco mosaic virus-coat protein & $T M V-C P$ & $\begin{array}{l}\text { Forward } \\
\text { Reverse }\end{array}$ & $\begin{array}{l}\text { ACGACTGCCGAAACGTTAGA } \\
\text { CAAGTTGCAGGACCAGAGGT }\end{array}$ & [64] \\
\hline
\end{tabular}

\subsection{Statistical Analysis}

The relative expression levels of the antivirus activity data were analysed by one-way analysis of variance (ANOVA) using CoStat software. At the same time, significant differences were determined according to the least significant difference (LSD) $p \leq 0.05$ level of probability, and the standard deviation (SD) is shown as a column bar. Compared to the controls, relative expression levels higher than 1 demonstrated an increase in gene expression (i.e., up-regulation), while values lower than 1 showed a decrease in expression levels (i.e., down-regulation). Data of the antifungal property (i.e., the inhibition percentage of fungal linear growth) as affected by the tested concentrations $(1 \%, 2 \%$, and $3 \%$ ) compared to the positive and negative controls were statistically analyzed using one-way ANOVA and processed with the Statistical Analysis Software (SAS) system [65]. The differences among the mean of the treatments were recorded using $\mathrm{LSD}_{0.05}$.

\section{Results}

\subsection{Polyphenolic Compounds in the Ethanol Extract}

Table 2 shows the polyphenolic compounds found in the ethanolic WPE of H. tuberculatum. The main polyphenolic compounds were resveratrol $(5178.58 \mathrm{mg} / \mathrm{kg})$, kaempferol $(1735.23 \mathrm{mg} / \mathrm{kg})$, myricetin $(561.18 \mathrm{mg} / \mathrm{kg})$, rutin $(487.04 \mathrm{mg} / \mathrm{kg})$, quercetin $(401.04 \mathrm{mg} / \mathrm{kg})$, and rosmarinic acid $(387.33 \mathrm{mg} / \mathrm{kg})$.

Table 2. Polyphenolic compounds identified in the ethanol extract of the Haplophyllum tuberculatum whole plant by High Performance Liquid Chromatography (HPLC).

\begin{tabular}{cc}
\hline Compound & Amount $\mathbf{( m g} / \mathbf{k g})$ \\
\hline Chlorogenic acid & ND \\
$p$-Coumaric acid & ND \\
Naringenin & ND \\
Pyrogallol & 8.35 \\
Gallic acid & 26.86 \\
Ferulic acid & 27.43 \\
Catechin & 33.85 \\
Quinol & 35.91 \\
Syringic acid & 39.63 \\
Caffeic acid & 45.14 \\
Vanillic acid & 45.39 \\
Ellagic acid & 46.79 \\
Cinnamic acid & 81.22 \\
$o$-Coumaric acid & 120.66 \\
Catechol & 199.51 \\
Benzoic acid & 221.47 \\
\hline -Hydroxy benzoic acid &
\end{tabular}


Table 2. Cont.

\begin{tabular}{cc}
\hline Compound & Amount $(\mathbf{m g} / \mathbf{k g})$ \\
\hline Rosmarinic acid & 387.33 \\
Quercetin & 401.04 \\
Rutin & 487.04 \\
Myricetin & 561.18 \\
kaempferol & 1735.23 \\
Resveratrol & 5178.58 \\
\hline
\end{tabular}

ND, not detected.

\subsection{Antifungal Property}

Figure 1 shows the inoculated wood treated with the tested concentrations (1\%, 2\%, and 3\%) prepared from the H. tuberculatum WPE with the two fungi F. culmorum and $R$. solani. It can be seen from the Petri dishes that with an increase in the extract concentration from $1 \%$ to $3 \%$, fungal linear growth was suppressed. In addition, the positive control ( $25 \mu \mathrm{g}$ of fluconazole) showed some inhibition in the growth of the tested fungi, while complete growth was recorded in the negative control $(10 \%$ DMSO). The results of the inhibition percentage of fungal linear growth (IPFLG) are presented in Table 3. H. tuberculatum WPE ( $3 \%)$ followed by H. tuberculatum WPE ( $2 \%)$ showed the highest IPFLGs of $82.96 \%$ and $72.96 \%$, respectively, against F. culmorum and were higher than $25 \mu \mathrm{g}$ of fluconazole $(53.70 \%)$. H. tuberculatum WPE at 3\%, 2\%, and 1\% showed the highest IPFLGs against $R$. solani with values of $93.70 \%, 66.29 \%$, and $49.62 \%$, respectively, which were more elevated than the value from $25 \mu \mathrm{g}$ of fluconazole $(42.96 \%)$.

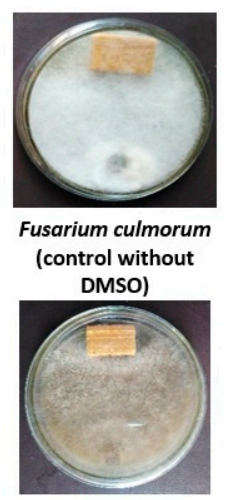

Rhizoctonia solani (control without DMSO)

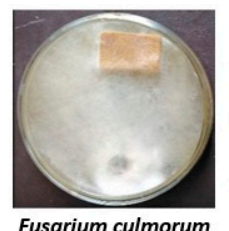

Fusarium culmorum (control with 10\%

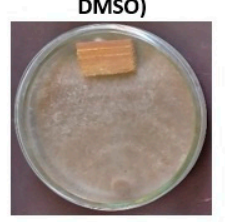

Rhizoctonia solani (control with 10\% DMSO)

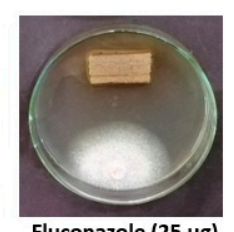

Fluconazole (25 $\mu \mathrm{g})$

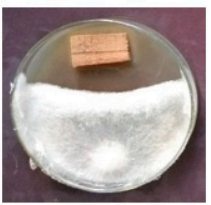

Fluconazole (25 $\mu \mathrm{g})$

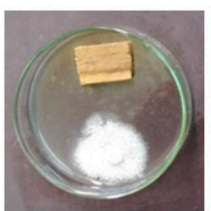

$1 \%$

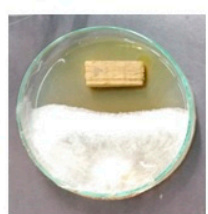

$1 \%$

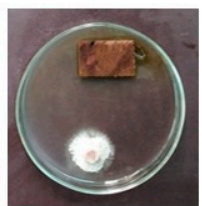

$2 \%$

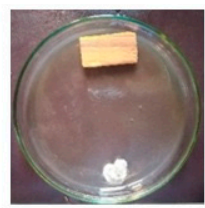

$3 \%$

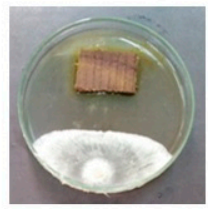

$2 \%$

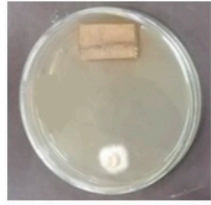

$3 \%$

Figure 1. Visual observation of the antifungal property of Haplophyllum tuberculatum whole plant extract (WPE) against Fusarium culmorum and Rhizoctonia solani.

Table 3. Antifungal property of wood treated with H. tuberculatum WPE against the growth of F. culmorum, and R. solani.

\begin{tabular}{ccc}
\hline \multirow{2}{*}{ Treatment } & \multicolumn{2}{c}{ Inhibition Percentage of Fungal Linear Growth (\%) } \\
\cline { 2 - 3 } & F. culmorum & R. solani \\
\hline H. tuberculatum WPE (1\%) & $46.29 \mathrm{~d} \pm 0.37^{*}$ & $49.62 \mathrm{c} \pm 0.37$ \\
H. tuberculatum WPE (2\%) & $72.96 \mathrm{~b} \pm 0.37$ & $66.29 \mathrm{~b} \pm 0.37$ \\
H. tuberculatum WPE (3\%) & $82.96 \mathrm{a} \pm 0.37$ & $93.70 \mathrm{a} \pm 0.37$ \\
Fluconazole (25 $\mu \mathrm{g})$ & $53.70 \mathrm{c} \pm 0.37$ & $42.96 \mathrm{~d} \pm 0.37$ \\
Control (DMSO 10\%) & $0.00 \mathrm{e}$ & $0.00 \mathrm{e}$ \\
LSD 0.05 & 1.04 & 1.04
\end{tabular}

* Values are reported as means \pm standard error (SE). Means with the letter within the same column are not significantly difference according to LSD0.05. DMSO: Dimethyl sulfoxide. 


\subsection{Effect of H. tuberculatum WPE on Disease Severity and TMV Accumulation Levels}

Under greenhouse conditions, the application of $H$. tuberculatum WPE $(200 \mu \mathrm{g} / \mathrm{mL})$ to C. amaranticolor plants significantly reduced the disease severity and decreased the TMV accumulation levels when compared to non-treated plants. The inhibitory effects of H. tuberculatum WPE were calculated by comparing the number of developed local lesions on the inoculated leaves at $5 \mathrm{dpi}$. In the protective assay, the calculated numbers of the local lesions on treated leaves ( $24 \mathrm{~h}$ before virus challenge) were significantly lower than that on non-treated leaves (Figure 2).
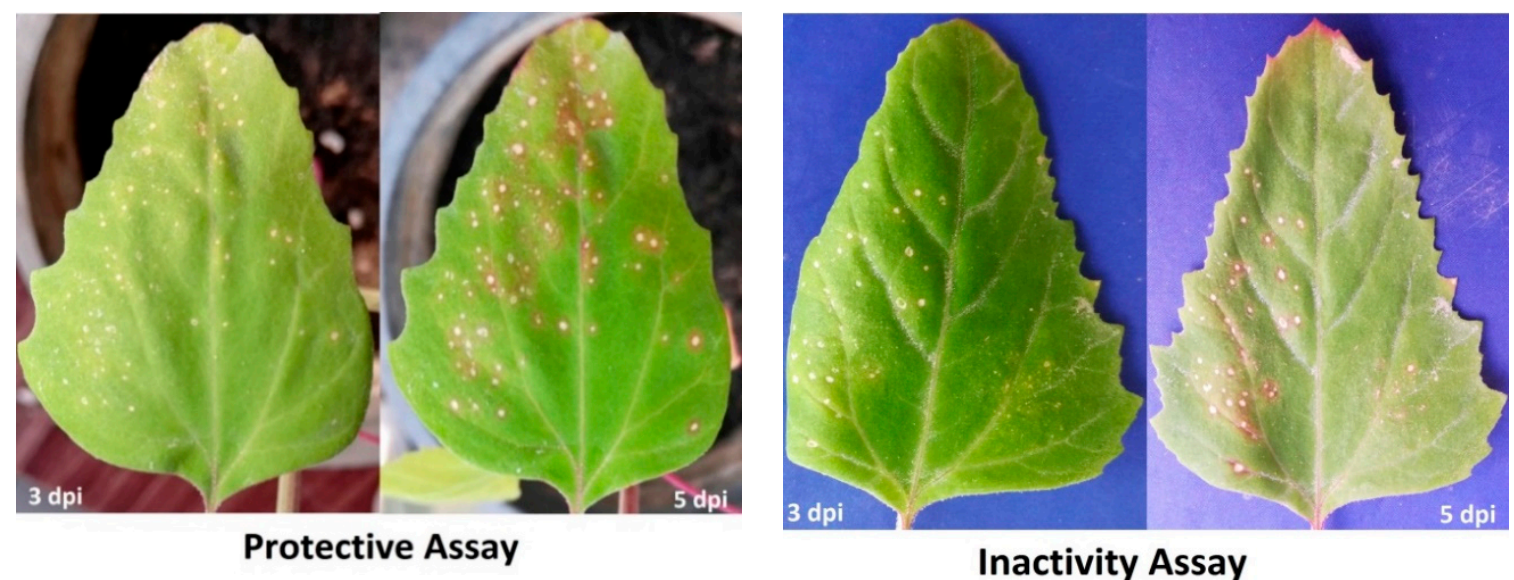

Figure 2. A photograph showing the disease symptoms on Chenopodium amaranticolor leaves infected with tobacco mosaic virus (TMV) at 3 and 5 days post-inoculation (dpi) of the protective activity and inactivity of $H$. tuberculatum whole plant extract (WPE) $(200 \mu \mathrm{g} / \mathrm{mL})$. The left-hand sides of the leaves were inoculated with TMV without any treatment, while the right-hand sides of the leaves were treated with WPE.

Moreover, the H. tuberculatum WPE showed an inhibitory effect of $65.38 \pm 2.4 \%$. On the other hand, the inactivity assay showed a higher inhibitory effect against TMV infection, with an inhibition rate of $95.73 \pm 1.2 \%$ (Figure 3). No symptoms were observed on the mock-treated plants. Meanwhile, by using a specific primer of TMV-CP, the level of TMV-CP transcripts significantly decreased in H. tuberculatum WPE-treated plant tissues when compared to non-treated tissues. Compared to mock tissues at $5 \mathrm{dpi}$, the non-treated tissues showed higher accumulation levels of TMV with relative accumulation levels of 28.918- and 27.042-fold change for the protective activity and inactivity treatments, respectively. Notably, H. tuberculatum WPE-treated tissues exhibited a considerably decreased TMV concentration level. Compared to the controls, the inactivity and protective activity treatments showed TMV accumulation levels of 2.470- and 3.499-fold change, respectively (Figure 3).

\subsection{Protective Assay: Changes in the Transcriptional Levels of PR-1, CHS, and HQT}

Figure 4 shows significant increases in the relative expression levels of PR-1, CHS, and HQT in plants treated with H. tuberculatum WPE when compared to that in non-treated plants $(p \leq 0.05)$ at 3 and 5 dpi. Compared to the controls, a significant up-regulation of PR- 1 with relative expressions of 1.926- and 7.467-fold change were observed in non-treated tissues at 3 and $5 \mathrm{dpi}$, respectively. However, H. tuberculatum WPE-treated tissues exhibited overexpression of PR-1 with relative expression levels of 12.436- and 14.750-fold change at 3 and $5 \mathrm{dpi}$, respectively, compared to the controls. For the CHS transcripts, at $3 \mathrm{dpi}$, up-regulation with a significant relative expression level of 1.778 -fold change was observed in H. tuberculatum WPE-treated tissues. In contrast, down-regulation with a relative expression level of 0.359 -fold change was observed in non-treated tissues when compared to the control tissues. On the other hand, up-regulation with relative expression levels of 1.880- and 2.512-fold change were showed in non-treated and $H$. tuberculatum WPE-treated tissues, respectively, at 5 dpi compared to the controls. Concerning the HQT gene, significant up-regulation with relative expression levels of 
1.340- and 1.573-fold change were shown only in H. tuberculatum WPE-treated tissues at 3 and 5 dpi, respectively, when compared to the controls. The down-regulation of HQT with relative transcriptional levels of 0.502- and 0.913-fold change lower than the controls was observed in non-treated tissues at 3 and $5 \mathrm{dpi}$, respectively. Consequently, treatment of $C$. amaranticolor tissues with $H$. tuberculatum WPE $24 \mathrm{~h}$ before TMV challenge induced the expression of HQT. However, TMV induced the expression of PR-1 and CHS, while the H. tuberculatum WPE applications triggered the expression of both genes at 3 and 5 dpi.

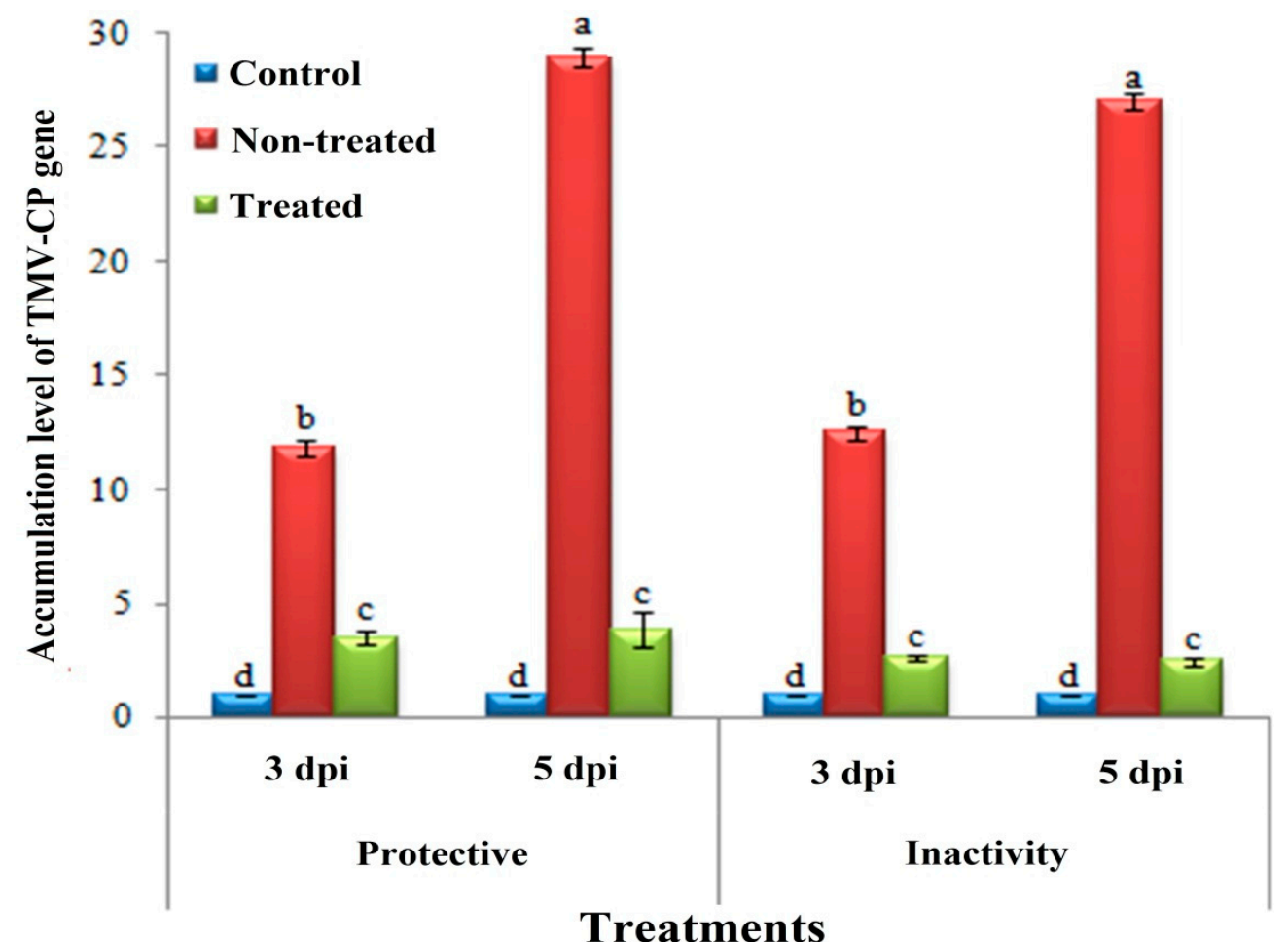

Figure 3. A histogram showing the accumulation levels of the TMV-CP gene at 3 and 5 days dpi with the protective activity and inactivity of $H$. tuberculatum WPE treatments $(200 \mu \mathrm{g} / \mathrm{mL})$. Control $=$ mock-treated plants; non-treated = plants inoculated with TMV only without any treatment; treated = plants treated with WPE, $24 \mathrm{~h}$ before inoculation of TMV for the protective assay and $24 \mathrm{~h}$ after inoculation of TMV for the inactivity assay. Columns represent a mean value from three biological replicates and the bars indicate the standard deviation (SD). Significant differences between samples were determined by one-way analysis of variance (ANOVA) using CoStat software. Means were separated by the least significant difference (LSD) test at $p \leq 0.05$ and indicated by lowercase letters. Columns with the same letter do not differ significantly. 


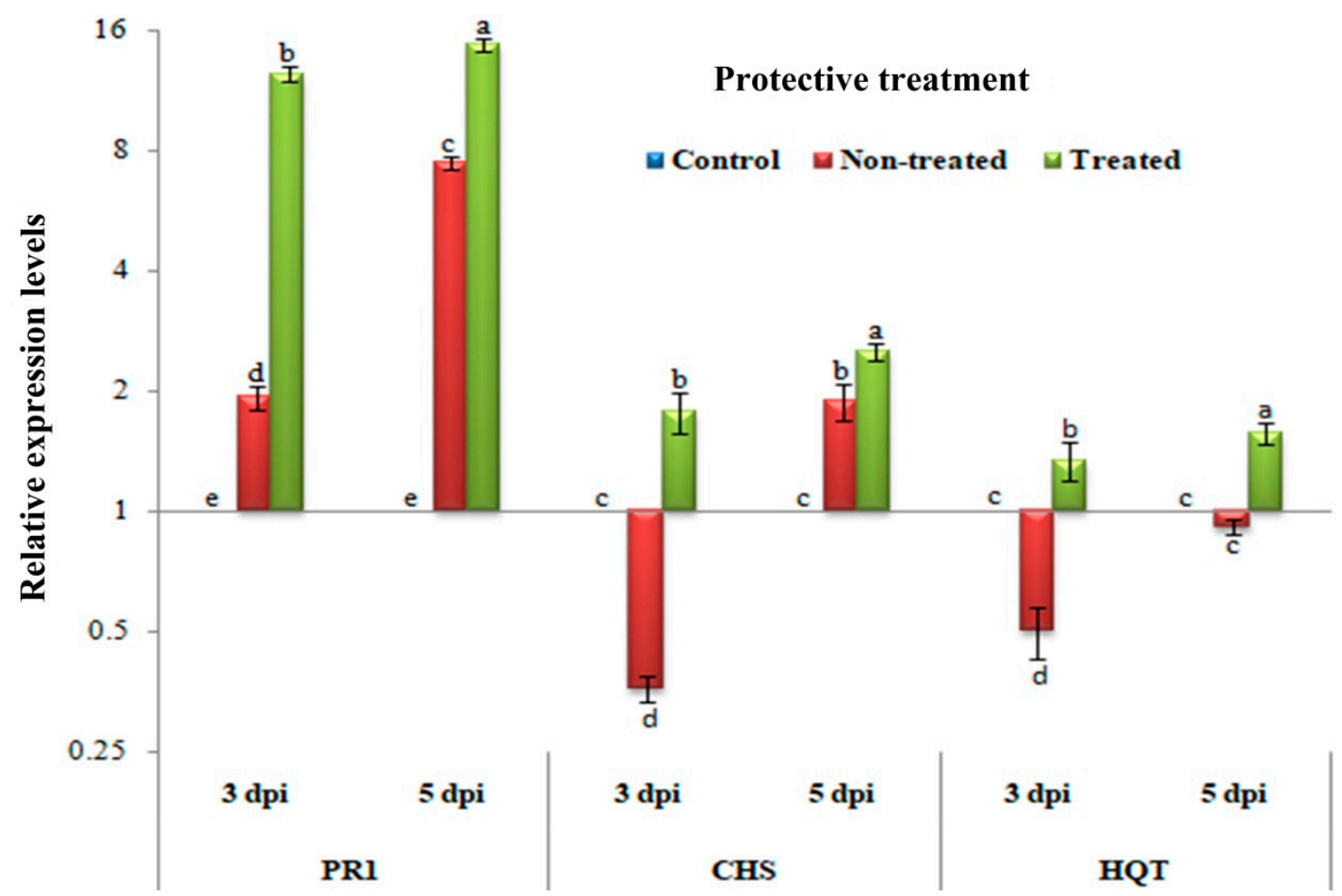

Figure 4. A histogram showing the relative expression levels of the PR-1, CHS, and HQT genes at 3 and 5 dpi of $H$. tuberculatum WPE treatments $(200 \mu \mathrm{g} / \mathrm{mL})$ in the protective activity assay. Control = mock-treated plants; non-treated = plants inoculated with TMV only without any treatment; treated = plants treated with $H$. tuberculatum WPE, $24 \mathrm{~h}$ before inoculation of TMV for the protective assay and $24 \mathrm{~h}$ after inoculation of TMV for the inactivity assay. Columns represent the mean value from three biological replicates and the bars indicate SD. Significant differences between samples were determined by one-way ANOVA using CoStat software. Means were separated by the LSD test at $p \leq 0.05$ and indicated by lowercase letters. Columns with the same letter do not differ significantly.

\subsection{Inactivity Assay: Changes in Transcriptional Levels of PR-1, CHS, and HQT}

In Figure 5, similarly to the protective treatment, significant increases in the relative expression levels of PR-1, CHS, and HQT were observed in plant tissues treated with H. tuberculatum WPE when compared to the control and non-treated plants $(p \leq 0.05)$ at 3 and 5 dpi. Compared to the mock tissues, a significant up-regulation of PR-1 with relative expression levels of 2.162- and 3.342-fold change was observed in non-treated tissues at 3 and $5 \mathrm{dpi}$, respectively. However, $H$. tuberculatum WPE-treated tissues showed an increase in the transcription of PR-1 with relative expression levels of 12.036- and 15.763-fold change at 3 and $5 \mathrm{dpi}$, respectively, compared to the controls. Regarding the CHS gene, down-regulation with a relative expression level of 0.815 -fold change was observed in non-treated tissues at $3 \mathrm{dpi}$. In contrast, $H$. tuberculatum WPE-treated tissues showed up-regulation with a significant relative expression level of 1.848 -fold change at the same time when compared to the control tissues. Subsequently, at $5 \mathrm{dpi}$, an increase in the expression with relative expression levels of 3.215- and 3.172-fold change was observed in non-treated and H. tuberculatum WPE-treated tissues, respectively. For the HQT transcripts, significant up-regulation with relative transcriptional levels of 1.470- and 1.401-fold change were found only in H. tuberculatum WPE-treated tissues at 3 and $5 \mathrm{dpi}$, respectively, when compared to the controls. Conversely, the non-treated tissues exhibited down-regulation of HQT with relative transcriptional levels of 0.603- and 0.795-fold change lower than the controls at 3 and 5 dpi, respectively. 


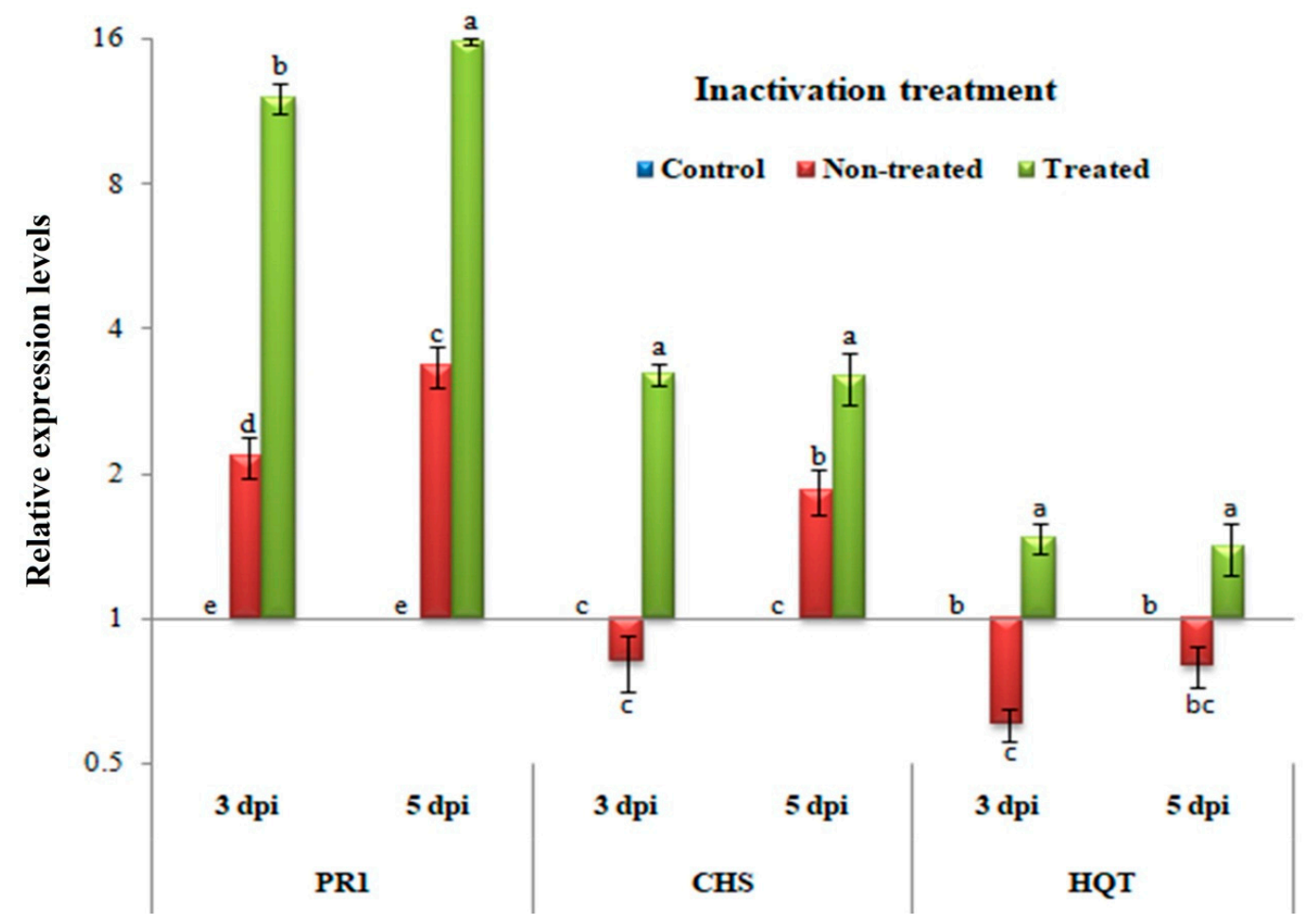

Figure 5. A histogram showing the relative expression levels of the PR-1, CHS, and HQT genes at 3 and $5 \mathrm{dpi}$ of $H$. tuberculatum WPE treatments $(200 \mu \mathrm{g} / \mathrm{mL})$ in the inactivity assay. Control = mock-treated plants; non-treated = plants inoculated with TMV only without any treatment; treated = plants treated with $H$. tuberculatum WPE, $24 \mathrm{~h}$ before inoculation of TMV for the protective assay and $24 \mathrm{~h}$ after inoculation of TMV for the inactivity assay. Columns represent a mean value from three biological replicates and bars indicate SD. Significant differences between samples were determined by one-way ANOVA using CoStat software. Means were separated by the LSD test at $p \leq 0.05$ and indicated by lowercase letters. Columns with the same letter do not differ significantly.

\section{Discussion}

Several polyphenolic compounds from the ethanolic WPE of $H$. tuberculatum were identified by HPLC, such as resveratrol, kaempferol, myricetin, rutin, quercetin, rosmarinic acid, catechol, p-hydroxybenzoic acid, and benzoic acid. The H. tuberculatum WPE showed the presence of total phenol content (TPC) ranging between 0.27 and $11.97 \mathrm{mg}$ gallic acid equivalent (GAE)/g dry matter and a whole flavonoid content from 0.05 to $1.50 \mathrm{mg}$ equivalent of rutin/g of dry matter [66]. The TPC was $46.2 \mathrm{mg} \mathrm{GA} / \mathrm{g}$ sample, and the main chemical constituents of quercetin derivatives, cinnamic acid, ferulic acid, vanillic acid, and benzoic acid were found in the ethanol extract of the aerial parts of H. tuberculatum [67]. The TPC was observed to be $561.22 \mathrm{mg} / \mathrm{g}$ of GAE and the flavonoids $165.54 \mathrm{mg} / \mathrm{g}$ of quercetin equivalent [68]. The ethyl acetate extract of $H$. tuberculatum leaves was the most abundant extract in phenolics and flavonoids, with $262 \mathrm{mg} \mathrm{GAE} / \mathrm{g}$ and $99.1 \mathrm{mg}$ quercetin equivalent/g of dry weight, respectively [42].

In the present study, all of the examined H. tuberculatum WPE concentrations exhibited antifungal properties against the linear growth of two fungal isolates compared with the positive control (fluconazole), which commercially used in a rapid susceptibility testing useful method to determine the optimal treatment for infection with resistant isolates [69].

Many strategies have been used to reduce agricultural losses caused by fungal diseases including spraying of chemicals, biological control [70], and azoles fungicide [71]. The azoles group gave high minimal inhibitory concentrations (MICs) against the most Fusarium species [72]. Candida albicans is usually acutely susceptible to fluconazole; fluconazole MICs for approximately $90 \%$ of C. albicans 
isolates are $\leq 1 \mu \mathrm{g} / \mathrm{mL}$ [73]. Some non-C. albicans yeasts have been noted to have decreased susceptibility or resistance to fluconazole [73].

Our recent research similarly showed the highest inhibition of R. solani, B. cinerea, and F. culmorum growth by $64.4 \%, 100 \%$, and $38.5 \%$, respectively, with the ethanol extract of Coccoloba uvifera L. at $3 \%$ [48]. The Eucalyptus camaldulensis L. aerial parts n-hexane extract showed the same strong fungicidal property against the two fungal isolates, F. culmorum and R. solani especially at the concentration of 3\% [50]. In the same way, wood samples treated with Acacia saligna water extract showed inhibition of fungal mycelial growth of F. culmorum and R. solani [15]. In a study performed by Sabry et al. [74] the ethanolic extract of the aerial parts of $H$. tuberculatum demonstrated an efficient antifungal property against Aspergillus fumigates, Geotricum candidum and Syncephalastrum racemosum with (MIC 0.49, 0.12, and $1.95 \mu \mathrm{g} / \mathrm{mL}$ ). While the antimicrobial tests of $H$. tuberculatum extracts were more effective against Gram-negative bacteria than Gram positive ones. The best antibacterial activity was exhibited by methanolic extract, which was also active against $C$. albicans [75].

Other works reported the cytotoxicity of the extracted parts of $H$. tuberculatum on other pests, and the hexane, chloroform, ethyl acetate, butanol, methanol, and water extracts of the leaves of H. tuberculatum displayed significant cytotoxic activity against brine shrimp larvae. At the same time, the ethanol extract of the aerial parts of $H$. tuberculatum has shown good insecticidal activity against Culex quinquefasciatus [38]. In comparison, the oil of $H$. tuberculatum has been observed to have a slightly antimicrobial effect on the growth of Escherichia coli, Salmonella choleraesuis, and Bacillus subtilis, as well as antifungal activity against $C$. lunata and F. oxysporum growth. Still, it does not affect the germination of their spores [40]. In a different way the fungicidal property of the H. tuberculatum might be went to its composition of flavonoids, tannins, phenolic acids, especially resveratrol, which displays better antifungal than antibacterial activity, as demonstrated by the minimum inhibitory concentrations (MICs). For the fungal species C. albicans, Saccharomyces cerevisiae and Trichosporon beigelii, the inhibitory activity is $10-20 \mu \mathrm{g} / \mathrm{mL}$ [76]. Resveratrol displays inhibitory activity against the plant pathogen $B$. cinerea, the causal agent of grey mold, where reduced germination of $B$. cinerea conidia and mycelial growth is observed at concentrations of $60-140 \mu \mathrm{g} / \mathrm{mL}$ [77]. While for the antibacterial activity the resveratrol exhibited MIC > 400 against the Gram negative bacteria, Escherichia coli, Salmonella enterica serovar Typhimurium, and Pseudomonas aeruginosa [78]. In our study, anti-TMV, protective, and inactivating, the activity of $H$. tuberculatum WPE on C. amaranticolor tissues using the half-leaf method [53] was investigated for the first time. Mainly, the inhibitory effects, accumulation levels of TMV CP, and relative expression levels of three defense-related genes (i.e., PR-1, CHS, and HQT) at 3 and 5 dpi were evaluated. Overall, our results indicated that $H$. tuberculatum WPE had an inhibitory effect against TMV infection. In the current study, the application of $H$. tuberculatum WPE $(200 \mu \mathrm{g} / \mathrm{mL})$ showed a significant reduction in local lesion symptoms when C. amaranticolor tissues were treated either $24 \mathrm{~h}$ before or with to viral challenge. The inactivity of $H$. tuberculatum WPE exhibited a strong inhibitory effect (approximately $96 \%$ ), while the protective activity showed an inhibitory effect of $65 \%$. The treatment of TMV with the aqueous extract of Bryophyllum daigremontianum $(200 \mathrm{mg} / \mathrm{mL})$ before mechanical inoculation significantly reduced the number of local lesions in N. tabacum var. Xanthi, N. glutinosa, and $V$. faba plants and showed inhibitory effects ranging from $51.45 \%$ to $86.08 \%$ [79]. The qPCR results confirmed the antiviral activity of $H$. tuberculatum WPE against TMV infection, which resulted in a considerable decrease in the viral accumulation level inside the treated tissues. The relative accumulation levels of TMV CP in C. amaranticolor tissues were 3.866- and 2.470-fold change in the protective activity and inactivity treatments, respectively, while non-treated tissues exhibited 28.918- and 27.042-fold change, respectively, at 5 dpi. These results suggest that $H$. tuberculatum WPE can directly inactivate TMV and may interfere with coat proteins or may inhibit viral replication inside plant cells. Jing et al. [31] reported that several plant extracts inhibited TMV infection through preventing the infection or spread of TMV, as well as the inhibition of viral replication.

In general, the direct and indirect inhibition of viral replication, through simultaneous activation of the host's innate immune system and by inducing SAR against viral infection, are two mechanisms 
of antiviral agents [31,37]. Regarding the stimulating effect on C. amaranticolor tissues, $H$. tuberculatum WPE induced and activated the expression of three defense-related genes (i.e., PR-1, CHS, and HQT).

PR-1 is considered a principal regulator of SAR and could be a marker of plant early defense responses [80]. Moreover, salicylic acid (SA) is a vital signal phytohormone molecule of SAR in plants [81], and its role in plant immunity has been known for over two decades. The activation of $\mathrm{SA}$ in response to pathogens is associated with the accumulation and expression of PR-1 as a SA marker gene [59]. In the present study, the non-treated C. amaranticolor tissues challenged with TMV showed induction of PR-1 with relative expression levels of 1.926- and 7.467-fold change and 2.162- and 3.342 -fold change in protective activity and inactivity treatments at 3 and $5 \mathrm{dpi}$, respectively. However, the $H$. tuberculatum WPE-treated tissues exhibited overexpression of PR-1 with transcriptional levels of 12.436- and 12.036-fold change in protective activity and inactivity treatments, respectively, at 3 dpi. At 5 dpi, PR-1 continued to accumulate, reaching maximum levels of 14.750- and 15.763-fold change in protective activity and inactivity treatments, respectively, when compared to the controls. Consequently, we suggest that $H$. tuberculatum WPE may contain elicitor molecules that activate the immune defense system besides the inhibition of TMV replication. In this context, tobacco plants treated with Sophora flavescens, Forsythia suspense, and Lonicera japonic extracts exhibiting the induction and up-regulation of PR-1 resulted in the development of SAR against TMV [82].

Besides, as the first enzyme in the flavonoid pathway that catalyzes the synthesis of naringenin chalcones, CHS is strictly required in various plant tissues for flavonoid production $[59,83]$. Compared to mock tissues at $3 \mathrm{dpi}$, the CHS transcripts were induced only in H. tuberculatum WPE-treated tissues with relative expression levels of 1.778- and 3.215-fold change for protective activity and inactivity treatments, respectively. At 5 dpi, up-regulation of CHS in non-treated tissues was observed, while $H$. tuberculatum WPE-treated tissues exhibited an increase in the transcriptional levels of CHS. The down-regulation of CHS at 3 dpi of non-treated tissues suggests that TMV infection suppresses naringenin chalcones biosynthesis in early infection. Interestingly, the application of $H$. tuberculatum WPE in the protective activity and inactivity assays showed the highest induction of CHS that is strictly required for flavonoid production naringenin chalcones, which are considered the primary precursors and constitute the main intermediates for the synthesis of many flavonoids by the action other enzyme sets $[8,84]$.

Chlorogenic acid (CGA), one of the most polyphenolic compounds, plays important roles in increasing plant resistance and in inhibiting pathogens, including viruses [85-87]. HQT is the key enzyme in the biosynthesis of CGA, while it catalyzes caffeoyl-CoA and quinic acid to form CGA [88]. In the present study, the transcription of CHS was wholly suppressed and down-regulated in non-treated tissues at 3 and 5 dpi of the protective activity and inactivity treatments when compared to the controls. The overexpression of HQT was associated with increases in chlorogenic acid content and versa [88]. Consequently, TMV was able to suppress chlorogenic acid biosynthesis inside infected tissues.

On the other hand, the application of H. tuberculatum WPE induced HQT transcripts in both treatments, i.e., protective activity and inactivity, at 3 and 5 dpi. A higher expression level of HQT (1.573-fold change) was shown in H. tuberculatum WPE-treated tissues of the protective activity assay at $5 \mathrm{dpi}$. In comparison, a high expression level of HQT in the inactivity assay (1.470-fold change) was observed at 3 dpi. Based on the current results, H. tuberculatum WPE induced and activated HQT transcripts that correlated with increasing CGA accumulation inside treated tissues.

\section{Conclusions}

We firstly examined $H$. tuberculatum WPE as a novel antiviral agent against plant viruses, and our results suggest that it contains compounds that penetrate plant cells, play significant roles in SAR, inhibit infection, and directly inactivate TMV. Consequently, H. tuberculatum WPE may be considered as a promising source of both antifungal and antiviral substances for practical use and for developing plant-derived compounds for the effective management of plant diseases. 
Author Contributions: Conceptualization, A.A., M.Z.M.S., and S.I.B.; methodology, A.A., M.Z.M.S. and S.I.B.; software, S.H.Q.; validation, A.A., M.Z.M.S., and S.I.B.; formal analysis, A.A., M.Z.M.S., and S.I.B.; investigation, A.A., M.Z.M.S., E.H., S.I.B. and S.H.Q.; resources, E.H., S.I.B. and S.H.Q.; data curation, A.A. and M.Z.M.S.; writing—original draft preparation, A.A., M.Z.M.S., E.H., and S.I.B.; writing-review and editing, A.A., M.Z.M.S., E.H., and S.I.B.; visualization, A.A., M.Z.M.S., and S.I.B.; supervision, S.I.B. and S.H.Q. All authors have read and agreed to the published version of the manuscript.

Funding: This research received no external funding.

Conflicts of Interest: The authors declare no conflict of interest.

\section{References}

1. Al-Muniri, R.M.S.; Hossain, M.A. Evaluation of antioxidant and cytotoxic activities of different extracts of folk medicinal plant Hapllophyllum tuberculatum. Egypt. J. Basic Appl. Sci. 2017, 4, 101-106. [CrossRef]

2. Abdelkhalek, A.; Ismail, I.A.; Dessoky, E.S.; El-Hallous, E.I.; Hafez, E. A tomato kinesin-like protein is associated with Tobacco mosaic virus infection. Biotechnol. Biotechnol. Equip. 2019, 33, 1424-1433. [CrossRef]

3. Bazzini, A.A.; Hopp, H.E.; Beachy, R.N.; Asurmendi, S. Infection and coaccumulation of Tobacco mosaic virus proteins alter microRNA levels, correlating with symptom and plant development. Proc. Natl. Acad. Sci. USA 2007, 104, 12157-12162. [CrossRef]

4. Abdelkhalek, A. Expression of tomato pathogenesis related genes in response to Tobacco mosaic virus. J. Anim. Plant Sci. 2019, 29, 1596-1602.

5. Scholthof, K.G.; Adkins, S.; Czosnek, H.; Palukaitis, P.; Jacquot, E.; Hohn, T.; Hohn, B.; Saunders, K.; Candresse, T.; Ahlquist, P. Top 10 plant viruses in molecular plant pathology. Mol. Plant Pathol. 2011, 12, 938-954. [CrossRef]

6. Gao, Q.-M.; Kachroo, A.; Kachroo, P. Chemical inducers of systemic immunity in plants. J. Exp. Bot. 2014, 65, 1849-1855. [CrossRef]

7. Elsharkawy, M.M.; Shimizu, M.; Takahashi, H.; Ozaki, K.; Hyakumachi, M. Induction of systemic resistance against Cucumber mosaic virus in Arabidopsis thaliana by Trichoderma asperellum SKT-1. Plant Pathol. J. 2013, 29, 193-200. [CrossRef]

8. Glala, A.A.; Hoda, A.M.; Fawzi, Z.F. Improving tomato plant growth, health, earliness, productivity and fruit quality by chemically induced systematic resistance. J. Appl. Sci. Res. 2005, 1, 362-372.

9. Hammerschmidt, R. Induced disease resistance: How do induced plants stop pathogens? Physiol. Mol. Plant Pathol. 1999, 55, 77-84. [CrossRef]

10. Lawton, K.A.; Friedrich, L.; Hunt, M.; Weymann, K.; Delaney, T.; Kessmann, H.; Staub, T.; Ryals, J. Benzothiadiazole induces disease resistance in Arabidopsis by activation of the systemic acquired resistance signal transduction pathway. Plant J. 1996, 10, 71-82. [CrossRef]

11. Benhamou, N.; Belanger, R. Benzothiazole-mediated induced resistance to Fusarium oxysporum f. sp. radicis in tomato. Plant Physiol. 1998, 118, 1203-1212. [CrossRef]

12. Šišić, A.; Baćanović, J.; Al-Hatmi, A.M.; Karlovsky, P.; Ahmed, S.A.; Maier, W.; De Hoog, G.S.; Finckh, M.R. The 'forma specialis' issue in Fusarium: A case study in Fusarium solani f. sp. pisi. Sci. Rep. 2018, 8, 1252.

13. Sabuquillo, P.; Cal, A.D.; Melgarejo, P. Biocontrol of tomato wilt by Penicillium oxalicum formulations in different crop conditions. Biol. Control 2006, 37, 256-265. [CrossRef]

14. Kim, J.; Kim, J.D. Inhibitory effect of algal extracts on mycelial growth of the tomato-wilt pathogen, Fusarium oxysporum f. sp. lycopersici. Mycobiol. 2008, 36, 242-248. [CrossRef]

15. Al-Huqail, A.A.; Behiry, S.I.; Salem, M.Z.M.; Ali, H.M.; Siddiqui, M.H.; Salem, A.Z.M. Antifungal, antibacterial, and antioxidant activities of Acacia saligna (Labill.) HL Wendl. flower extract: HPLC analysis of phenolic and flavonoid compounds. Molecules 2019, 24, 700. [CrossRef]

16. Lewis, J.A.; Lumsden, R.D.; Locke, J.C. Biocontrol of damping-off diseases caused by Rhizoctonia solani and Pythium ultimum with alginate prills of Gliocladium virens, Trichoderma hamatum and various food bases. Biocontrol Sci. Technol. 1996, 6, 163-173. [CrossRef]

17. Fravel, D.; Olivain, C.; Alabouvette, C. Fusarium oxysporum and its biocontrol. New Phytol. 2003, 157, 493-502. [CrossRef]

18. Hibar, K.; Daami-Remadi, M.; Jabnoun-Khiareddine, H.; El Mahjoub, M. Fusarium crown and root rot and its chemical control. Int. J. Agric. Res. 2007, 2, 687-695. 
19. Dissanayake, M.L.M.C.; Jayasinghe, J.A.N. Antifungal activity of selected medicinal plant extracts against plant pathogen fungi; Rhizoctonia solani, Colletotrichum musea and Fusarium oxysporum. Int. J. Sci. Invent. Today 2013, 2, 421-431.

20. Kagale, S.; Marimuthu, T.; Nandakumar, R.; Samiyappan, R. Antimicrobial activity and induction of systemic resistance in rice by leaf extract of Datura metel against Rhizoctonia solani and Xanthomonas oryzae pv. Oryzae. Physiol. Mol. Plant Pathol. 2004, 65, 91-100. [CrossRef]

21. Mahesh, B.; Satish, S. Antimicrobial activity of some important medicinal plant against plant and human pathogens. World J. Agric. Sci. 2008, 4, 839-843.

22. Raza, W.; Ghazanfar, M.U.; Iftikhar, Y.; Ahmed, K.S.; Haider, N.; Rasheed, M.H. Management of early blight of tomato through the use of plant extracts. Int. J. Zool. Stud. 2016, 1, 1-4.

23. Bennett, R.N.; Wallsgrove, R.M. Secondary metabolites in plant defense mechanisms. New Phytol. 1994, 127, 617-633. [CrossRef]

24. Osbourne, A.E. Preformed antimicrobial compounds and plant defense against fungal attack. Plant Cell 1996, 8, 1821-1831. [CrossRef]

25. Cowan, M.M. Plant products as antimicrobial agents. Clin. Microbiol. Rev. 1999, 12, 564-582. [CrossRef]

26. Tapwal, A.; Garg, S.; Gautam, N.; Kumar, R. In vitro antifungal potency of plant extracts against five phytopathogens. Braz. Arch. Biol. Technol. 2011, 54, 1093-1098. [CrossRef]

27. Mengal, A.S.; Hussain, S.; Ali, M.; Abro, M.A.; Jatoi, G.H.; Nisa, N.; Rafiq, M.; Iqbal, S. Evaluation of different botanical extracts on the linear colony growth of the fungus Fusarium wilt of mango nursery and its in-vitro control. Eur. J. Biotechnol. Biosci. 2015, 3, 7-14.

28. Darmadi, A.A.K.; Suprapta, D.N.; Ginantra, I.K. Effect of cinnamon leaf extract formula (Cinnamomum burmanni Blume) on Fusarium wilt that attacks tomato plants in Bali. Int. J. Pure Appl. Biosci. 2016, 4, 33-38. [CrossRef]

29. Neela, F.A.; Sonia, I.A.; Shamsi, S. Antifungal activity of selected medicinal plant extract on Fusarium oxysporum Schecht the causal agent of Fusarium wilt disease in tomato. Am. J. Plant Sci. 2014, 5, 2665-2671. [CrossRef]

30. Abdelkhalek, A.; Hafez, E. Plant viral diseases in Egypt and their control. In Cottage Industry of Biocontrol Agents and Their Applications; Springer: Berlin, Germany, 2020; pp. 403-421.

31. Jing, B.N.; Ma, Z.Q.; Feng, J.T.; Liang, H.H.Y.; Li, C.; Zhang, X. Evaluation of the antiviral activity of extracts from plants grown in the Qinling Region of China against infection by Tobacco mosaic virus (TMV). J. Phytopathol. 2012, 160, 181-186. [CrossRef]

32. Shen, J.G.; Wu, Z.J.; Xie, L.H.; Lin, Q.Y. Antiviral effect of medicinal plant extracts on tobacco mosaic virus. Zhong Cao Yao 2006, 37, 259-261. (In Chinese)

33. Verma, H.; Awasthi, L. Antiviral activity of Boerhaavia diffusa root extract and the physical properties of the virus inhibitor. Can. J. Bot. 1979, 57, 926-932. [CrossRef]

34. Verma, H.; Kumar, V. Prevention of plant virus diseases by Mirabilis jalapa leaf extract. New Bot. 1980, 7, 87-91.

35. Jassim, S.A.; Naji, M.A. Novel antiviral agents: A medicinal plant perspective. J. Appl. Microbiol. 2003, 95, 412-427. [CrossRef]

36. Elbeshehy, E.K.; Metwali, E.M.; Almaghrabi, O.A. Antiviral activity of Thuja orientalis extracts against watermelon mosaic virus (WMV) on Citrullus lanatus. Saudi J. Biol. Sci. 2015, 22, 211-219. [CrossRef]

37. Waziri, H.M.A. Plants as antiviral agents. J. Plant Pathol. Microb. 2015, 6, 254. [CrossRef]

38. Mohsen, Z.H.; Jaffer, H.J.; Al-Saad, M.; Ali, Z.S. Insecticidal effects of Haplophyllum tuberculatum against Culex quinquefasciatus. Int. J. Crude Drug Res. 1989, 27, 17-21. [CrossRef]

39. Onifade, A.K.; Fatope, M.O.; Deadman, M.L.; Al-Kindy, S.M.Z. Nematicidal activity of Haplophyllum tuberculatum and Plectranthuscy lindraceus oils against Meloidogyne javanica. Biochem. Syst. Ecol. 2008, 36, 679-683. [CrossRef]

40. Al-Burtamani, S.K.S.; Fatope, M.O.; Marwah, R.G.; Onifade, A.K.; Al-Saidi, S.H. Chemical composition, antibacterial and antifungal activities of the essential oil of Haplophyllum tuberculatum from Oman. J. Ethnopharmacol. 2005, 96, 107-112. [CrossRef]

41. Sheriha, G.M.; Abouamer, K.; Elshtaiwi, B.Z. An alkaloid from Haplophyllum tuberculatum. Phytochemistry 1985, 24, 884-886. [CrossRef] 
42. Hamdi, A.; Viane, J.; Mahjoub, M.A.; Majouli, K.; Gad, M.H.H.; Kharbach, M.; Demeyer, K.; Marzouk, Z.; Vander Heyden, Y. Polyphenolic contents, antioxidant activities and UPLC-ESI-MS analysis of Haplophyllum tuberculatum A. Juss leaves extracts. Int. J. Biol. Macromol. 2018, 106, 1071-1079. [CrossRef]

43. Hamdi, A.; Majouli, K.; Flamini, G.; Marzouk, B.; Marzouk, Z.; Heyden, Y.V. Antioxidant and anticandidal activities of the Tunisian Haplophyllum tuberculatum (Forssk.) A. Juss. essential oils. S. Afr. J. Bot. 2017, 112, 210-214. [CrossRef]

44. Salem, M.Z.M.; Mansour, M.M.A.; Elansary, H.O. Evaluation of the effect of inner and outer bark extracts of Sugar Maple (Acer saccharum var. saccharum) in combination with citric acid against the growth of three common molds. J. Wood Chem. Technol. 2019, 39, 136-147. [CrossRef]

45. Behiry, S.I.; Okla, M.K.; Alamri, S.A.; EL-Hefny, M.; Salem, M.Z.M.; Alaraidh, I.A.; Ali, H.M.; Al-Ghtani, S.M.; Monroy, J.C.; Salem, A.Z.M. Antifungal and antibacterial activities of Musa paradisiaca L. peel extract: HPLC analysis of phenolic and flavonoid contents. Processes 2019, 7, 215. [CrossRef]

46. Salem, M.Z.M.; Ibrahim, I.H.M.; Ali, H.M.; Helmy, H.M. Assessment the using of natural extracted dyes and pancreatin enzyme for dyeing of four natural textiles: HPLC analysis of phytochemicals. Processes 2020, 8 , 59. [CrossRef]

47. Abdelkhalek, A.; Salem, M.Z.M.; Kordy, A.M.; Salem, A.Z.M.; Behiry, S.I. Antiviral, antifungal, and insecticidal activities of Eucalyptus bark extract: HPLC analysis of polyphenolic compounds. Microb. Pathog. 2020, 147, 104383. [CrossRef]

48. Ashmawy, N.A.; Salem, M.Z.M.; El Shanhorey, N.; Al-Huqail, A.; Ali, H.M.; Behiry, S.I. Eco-friendly wood-biofungicidal and antibacterial activities of various Coccoloba uvifera L. Leaf Extracts: HPLC analysis of phenolic and flavonoid compounds. BioResources 2020, 15, 4165-4187.

49. Behiry, S.I.; Nasser, R.A.; Abd El-Kareem, M.S.M.; Ali, H.M.; Salem, M.Z.M. Mass spectroscopic analysis, MNDO quantum chemical studies and antifungal activity of essential and recovered oil constituents of lemon-scented gum against three common molds. Processes 2020, 8, 275. [CrossRef]

50. Salem, M.Z.M.; Behiry, S.I.; EL-Hefny, M. Inhibition of Fusarium culmorum, Penicillium chrysogenum and Rhizoctonia solani by $n$-hexane extracts of three plant species as a wood-treated oil fungicide. J. Appl. Microbiol. 2019, 126, 1683-1699. [CrossRef]

51. EL-Hefny, M.; Salem, M.Z.M.; Behiry, S.I.; Ali, H.M. The potential antibacterial and antifungal activities of wood treated with Withania somnifera fruit extract, and the phenolic, caffeine and flavonoid composition of the extract according to HPLC. Processes 2020, 8, 113. [CrossRef]

52. Gooding, G.V.J.; Hebert, T.T. A simple technique for purification of tobacco mosaic virus in large quantities. Phytopathology 1967, 57, 1285-1287.

53. Kubo, S.; Ikeda, T.; Imaizumi, S.; Takanami, Y.; Mikami, Y. A potent plant virus inhibitor found in Mirabilis jalapa L. Ann. Phytopathol. Soc. Jpn. 1990, 56, 481-487. [CrossRef]

54. Hafez, E.E.; El-Morsi, A.A.; El-Shahaby, O.A.; Abdelkhalek, A.A. Occurrence of Iris yellow spot virus from onion crops in Egypt. Virus Dis. 2014, 25, 455-459. [CrossRef]

55. Abdelkhalek, A.; Sanan-Mishra, N. Differential expression profiles of tomato miRNAs induced by Tobacco mosaic virus. J. Agric. Sci. Technol. 2019, 21, 475-485.

56. Abdelkhalek, A.; Al-Askar, A. Green synthesized ZnO nanoparticles mediated by Mentha Spicata extract induce plant systemic resistance against Tobacco mosaic virus. Appl. Sci. 2020, 10, 5054. [CrossRef]

57. Abdelkhalek, A.; ElMorsi, A.; AlShehaby, O.; Sanan-Mishra, N.; Hafez, E. Identification of genes differentially expressed in Iris yellow spot virus infected onion. Phytopathol. Mediterr. 2018, 57, 334-340.

58. ElMorsi, A.; Abdelkhalek, A.; AlShehaby, O.; Hafez, E. Pathogenesis-related genes as tools for discovering the response of onion defence system against Iris yellow spot virus infection. Botany 2015, 93, 735-744. [CrossRef]

59. Abdelkhalek, A.; Al-Askar, A.A.; Hafez, E. Differential induction and suppression of the potato innate immune system in response to Alfalfa mosaic virus infection. Physiol. Mol. Plant Pathol. 2020, 110, 101485. [CrossRef]

60. Livak, K.J.; Schmittgen, T.D. Analysis of relative gene expression data using real-time quantitative PCR and the 2(-Delta Delta C(T)) method. Methods 2001, 25, 402-408. [CrossRef] [PubMed]

61. Kavroulakis, N.; Papadopoulou, K.K.; Ntougias, S.; Zervakis, G.I.; Ehaliotis, C. Cytological and other aspects of pathogenesis-related gene expression in tomato plants grown on a suppressive compost. Ann. Bot. 2006, 98, 555-564. [CrossRef] [PubMed] 
62. André, C.M.; Schafleitner, R.; Legay, S.; Lefèvre, I.; Aliaga, C.A.A.; Nomberto, G.; Hoffmann, L.; Hausman, J.-F.; Larondelle, Y.; Evers, D. Gene expression changes related to the production of phenolic compounds in potato tubers grown under drought stress. Phytochemistry 2009, 70, 1107-1116. [CrossRef] [PubMed]

63. Pasumarthy, K.K.; Mukherjee, S.K.; Choudhury, N.R. The presence of tomato leaf curl Kerala virus AC3 protein enhances viral DNA replication and modulates virus induced gene-silencing mechanism in tomato plants. Virol. J. 2011, 8, 178. [CrossRef] [PubMed]

64. Zhao, L.; Dong, J.; Hu, Z.; Li, S.; Su, X.; Zhang, J.; Yin, Y.; Xu, T.; Zhang, Z.; Chen, H. Anti-TMV activity and functional mechanisms of two sesquiterpenoids isolated from Tithonia diversifolia. Pestic. Biochem. Physiol. 2017, 140, 24-29. [CrossRef] [PubMed]

65. SAS. User Guide: Statistics (Release 8.02); SAS Institute: Cary, NC, USA, 2001.

66. Chaoua, H.; Khacheba, I.; Boussoussa, H.; Bekhaoua, A.; Yousfi, M. A Potent in Vitro $\alpha$-Amylase Inhibitory Action of Haplophyllum tuberculatum Extracts. Curr. Enzym. Inhib. 2019, 15, 190-196. [CrossRef]

67. Eissa, T.F.; González-Burgos, E.; Carretero, M.E.; Gómez-Serranillos, M.P. Biological activity of HPLC-characterized ethanol extract from the aerial parts of Haplophyllum tuberculatum. Pharm. Biol. 2014, 52, 151-156. [CrossRef]

68. Aziza, S.B.; Hebbatallah, A.A.; Maha, A.H.; Shah, A.K. Evaluation of antioxidant potential, total phenolic content and phytochemical screening of aerial parts of a folkloric medicine. Haplophyllum tuberculatum (Forssk) A. Juss. J. Coast Life Med. 2016, 4, 315-319.

69. Rex, J.H.; Pfaller, M.A.; Rinaldi, M.G.; Polak, A.; Galgiani, J.N. Antifungal susceptibility testing. Clin. Microbiol. Rev. 1993, 6, 367-381. [CrossRef]

70. Singh, R.P.; Singh, P.K.; Rutkoski, J.; Hodson, D.P.; He, X.; Jørgensen, L.N.; Hovmøller, M.S.; Huerta-Espino, J. Disease impact on wheat yield potential and prospects of genetic control. Annu. Rev. Phytopathol. 2016, 54, 303-322. [CrossRef]

71. Hof, H. Critical annotations to the use of azole antifungals for plant protection. Antimicrob. Agents Chemother. 2001, 45, 2987-2990. [CrossRef]

72. Al-Hatmi, A.M.S.; van Diepeningen, A.D.; Curfs-Breuker, I.; de Hoog, G.S.; Meis, J.F. Specific antifungal susceptibility profiles of opportunists in the Fusarium fujikuroi complex. J. Antimicrob. Chemother. 2015, 70, 1068-1071. [CrossRef]

73. Rex, J.H.; Rinaldi, M.G.; Pfaller, M.A. Resistance of Candida species to fluconazole. Antimicrob. Agents Chemother. 1995, 39, 1-8. [CrossRef]

74. Sabry, O.M.; EI Sayed, A.M.; Sleem, A.A. Potential Anti-Microbial, Anti-Inflammatory and Anti-Oxidant Activities of Haplophyllum tuberculatum growing in Libya. J. Pharmacogn. Nat. Prod. 2016, 2, 116. [CrossRef]

75. Debouba, M.; Khemakhem, B.; Zouari, S.; Meskine, A.; Gouia, H. Chemical and biological activities of Haplophyllum tuberculatum organic extracts and essential oil. J. Essent. Oil Bear. Plants 2014, 17, 787-796. [CrossRef]

76. Jung, H.J.; Hwang, I.A.; Sung, W.S.; Kang, H.; Kang, B.S.; Seu, Y.B.; Lee, D.G. Fungicidal effect of resveratrol on human infectious fungi. Arch. Pharmacal Res. 2005, 28, 557-560. [CrossRef]

77. Adrian, M.; Jeandet, P.; Veneau, J.; Weston, L.A.; Bessis, R. Biological activity of resveratrol, a stilbenic compound from grapevines, against Botrytis cinerea, the causal agent for gray mold. J. Chem. Ecol. 1997, 23, 1689-1702. [CrossRef]

78. Paulo, L.; Ferreira, S.; Gallardo, E.; Queiroz, J.A.; Domingues, F. Antimicrobial activity and effects of resveratrol on human pathogenic bacteria. J. Microbiol. Biotechnol. 2010, 26, 1533-1538. [CrossRef]

79. Shahriari, A.G.; Ghodoum Parizipour, M.H. Antiviral activity of aqueous extract of alligator plant, Bryophyllum daigremontianum L., against RNA and DNA plant viruses. J. Crop Prot. 2019, 8, 465-478.

80. Hoegen, E.; Strömberg, A.; Pihlgren, U.; Kombrink, E. Primary structure and tissue-specific expression of the pathogenesis-related protein PR-1b in potato. Mol. Plant Pathol. 2002, 3, 329-345. [CrossRef]

81. Vlot, A.C.; Dempsey, D.A.; Klessig, D.F. Salicylic acid, a multifaceted hormone to combat disease. Annu. Rev. Phytopathol. 2009, 47, 177-206. [CrossRef]

82. Wang, R.; Wang, S.; Pan, W.; Li, Q.; Xia, Z.; Guan, E.; Zheng, M.; Pang, G.; Yang, Y.; Yi, Z. Strategy of tobacco plant against black shank and Tobacco mosaic virus infection via induction of PR-1, PR-4 and PR-5 proteins assisted by medicinal plant extracts. Physiol. Mol. Plant Pathol. 2018, 101, 127-145. [CrossRef] 
83. Kang, J.H.; McRoberts, J.; Shi, F.; Moreno, J.E.; Jones, A.D.; Howe, G.A. The flavonoid biosynthetic enzyme chalcone isomerase modulates terpenoid production in glandular trichomes of tomato. Plant Physiol. 2014, 164, 1161-1174. [CrossRef]

84. Marais, J.P.J.; Deavours, B.; Dixon, R.A.; Ferreira, D. The stereochemistry of flavonoids. In The Science of Flavonoids; Grotewold, E., Ed.; Springer: Columbus, OH, USA, 2006.

85. Tsao, R.; Marvin, C.H.; Broadbent, A.B.; Friesen, M.; Allen, W.R.; McGarvey, B.D. Evidence for an isobutylamide associated with host-plant resistance to western flower thrips, Frankliniella occidentalis, in chrysanthemum. J. Chem. Ecol. 2005, 31, 103-110. [CrossRef] [PubMed]

86. Leiss, K.A.; Maltese, F.; Choi, Y.H.; Verpoorte, R.; Klinkhamer, P.G.L. Identification of chlorogenic acid as a resistance factor for thrips in chrysanthemum. Plant Physiol. 2009, 150, 1567-1575. [CrossRef] [PubMed]

87. Abdelkhalek, A.; Dessoky, E.S.; Hafez, E. Polyphenolic genes expression pattern and their role in viral resistance in tomato plant infected with Tobacco mosaic virus. Biosci. Res. 2018, 15, 3349-3356.

88. Niggeweg, R.; Michael, A.J.; Martin, C. Engineering plants with increased levels of the antioxidant chlorogenic acid. Nat. Biotechnol. 2004, 22, 746-754. [CrossRef] [PubMed]

(C) 2020 by the authors. Licensee MDPI, Basel, Switzerland. This article is an open access article distributed under the terms and conditions of the Creative Commons Attribution (CC BY) license (http://creativecommons.org/licenses/by/4.0/). 